\title{
Replication of the Human Immunodeficiency Virus 1 and Impaired Differentiation of T Cells after In Vitro Infection of Bone Marrow Immature T Cells
}

\author{
Y. Lunardi-Iskandar, ${ }^{\star}$ M. T. Nugeyre, ${ }^{\ddagger}$ V. Georgoulias, ${ }^{*}$ F. Barré-Sinoussi, ${ }^{\ddagger}$ C. Jasmin," and J. C. Chermann \\ *Unité d'Oncogénèse Appliquée (Institut Nationale de la Santé et de la Recherche Medicale), Hôpital Paul Brousse, B.P. 200,94804 \\ Villejuif Cédex, France; and ${ }^{\ddagger}$ Laboratoire de Biologie des Rétrovirus, Institut Pasteur, 75015 Paris, France
}

\begin{abstract}
HIV-1 infection in vitro of normal bone marrow mononuclear cells (BMMC) depleted of mature T cells was studied. BMMC depleted of either CD3, CD2, or both could replicate HIV-1 irrespective of the presence of macrophages/monocytes. Infected bone marrow cells were shown to differentiate during the culture into $\mathrm{CD3}^{+}, \mathrm{CD4}^{+}, \mathrm{CD8}^{+}$, and $\mathrm{CD1}^{+}$cells, whereas noninfected $\mathrm{BMMC}$ gave rise to $\mathrm{CD3}^{+}, \mathrm{CD4}^{+}$, and $\mathrm{CD8}^{+}$cells. Moreover, 9-14\% of the cells also expressed the viral proteins p24 and gp120 on their surface. Double staining studies revealed that 72 and $83 \%$ of the $\mathrm{CD4}^{+}$cells expressed the gp1 20 and $\mathbf{p 2 4}$, respectively, suggesting that virus replication occurred in $\mathrm{CD4}^{+}$cells. $\mathrm{T}$ cell colony growth from infected BMMC, either unfractionated or depleted of mature $T$ cells, was impaired in a time-dependent manner, and the differentiation capacity of $\mathrm{T}$ cell precursors was abnormal. Colony cells displayed an immature cell phenotype $\left(\mathrm{CD1}^{+}\right.$cells) and the viral proteins gp120 and/or p24 could also be detected on $\mathrm{CD1}^{+}$cells. In addition, pooled colony cells derived from infected $\mathrm{CD}_{2}$ - and $\mathrm{CD}_{3}$-depleted $\mathrm{BMMC}$ could infect normal mitogen-activated lymphocytes in coculture experiments. These findings strongly suggest that HIV-1 can infect immature bone marrow $T$ cells and be transmitted to the progeny, but the massive viral replication occurs only when the cells differentiate toward $\mathrm{CD4}^{+}$cells.
\end{abstract}

\section{Introduction}

AIDS is etiologically linked to a human lentivirus known as HIV-1 $(1,2)$. HIV-1 can infect a variety of cellular targets such as the $\mathrm{CD}^{+}$helper lymphocytes $(3,4)$ and Epstein-Barrtransformed B lymphocytes $(5,6)$, as well as $\mathrm{CD}^{+}$macrophages $(7,8)$, endothelial cells $(9,10)$, and glial cells $(11,12)$. The virus has been shown to be cytopathogenic for $\mathrm{CD} 4^{+}$cells $(3,4)$.

AIDS and HIV-1 infection are usually associated with a variety of hematological abnormalities. The syndrome is mainly characterized by lymphopenia, which can be partially explained by the selective CD4 tropism of HIV-1 and the bind-

This paper was presented in part at the Third International Congress on AIDS, Washington, DC, 1987.

Address correspondence to Dr. V. Georgoulias, INSERM U 268, Hôpital Paul Brousse, BP 200, 94804 Villejuif Cédex, France.

Received for publication 8 June 1988 and in revised form 16 September 1988.

J. Clin. Invest.

(c) The American Society for Clinical Investigation, Inc. 0021-9738/89/02/0610/06 \$2.00

Volume 83, February 1989, 610-615 ing of the HIV-1 glycoprotein (gp120) to the CD4 molecules, which leads to syncytia formation and cell death. Although the CD4 molecule has been defined as the cell receptor for HIV (13-16), the use of fluoresceinated antibodies against viral encoded proteins and in situ hybridization techniques (17-19) has shown that only an extremely small percentage of cells (5-10\%) in the peripheral blood of HIV-infected individuals are expressing virus at any given time. These observations suggest that additional mechanisms could be involved in the pathophysiology of the T cell lymphopenia and impairment of $T$ cell function.

$\mathrm{T}$ cell lymphocytes are the progeny of committed precursors ( $\mathrm{T}$ colony-forming cells $[\mathrm{T}-\mathrm{CFC}])^{1}$ that can proliferate and differentiate in vitro (20-22). Any abnormality of the T-CFC proliferation and differentiation might allow significant alterations of the peripheral blood $T$ cells and could explain, at least in part, the impaired cell-mediated immunity during HIV-1 infection. Indeed, recently it has been shown that immunopurified viral envelope gp120 (23) as well as disrupted HIV preparations (24) could inhibit the $T$ cell activation capacity. Moreover, we have reported that adherent cells from some AIDS patients spontaneously produce an activity that inhibits the proliferation of normal $\mathrm{T}$ cells through a decreased expression of the Tac (p55) chain of the IL-2 receptors (IL-2R) and a decreased production IL-2 (25). However, it is still unclear whether HIV can infect immature cells of the T cell lineage.

The aim of the present study was to investigate the effect of HIV on the proliferation and differentiation of immature bone marrow $\mathrm{T}$ cells as well as T-CFC. Our findings indicate that T cell-depleted bone marrow cells can be infected in vitro by HIV but virus replication occurs when the immature $T$ cells have differentiated into $\mathrm{CD}^{+}$cells. Moreover, HIV induced an impaired proliferation and differentiation capacity of T-CFC that was similar to that already observed in AIDS and lymphadenopathy syndrome (LAS) patients (26-29).

\section{Methods}

Cells. An aliquot of bone marrow aspirate was obtained from HIV-1 seronegative normal donors during the procedure of bone marrow transplantation after informed consent, and from clinically cadaveric marrow. Bone marrow mononuclear cells (BMMC) were separated by Ficoll gradient density centrifugation as reported $(26,27)$. Cell viability was tested by trypan blue dye exclusion and the cells were resuspended at $10^{6} \mathrm{BMMC} / \mathrm{ml}$ in RPMI 1640 (Gibco Laboratories, Grand Island, NY) supplemented with 10\% FCS (Gibco Laboratories), 2 mM L-glutamine (Gibco Laboratories), and antibiotics. BMMC were further

1. Abbreviations used in this paper: BMMC, bone marrow mononuclear cells; IL-2-R, IL-2 receptors; LAS, lymphadenopathy syndrome; RT, reverse transcriptase; T-CFC, T colony-forming cells. 
purified by complement-mediated cytotoxicity using the OKT3 (CD3; Ortho Pharmaceutical, Raritan, NJ) and/or T11 (CD2; Coulter Electronics Inc., Hialeah, FL) MAbs and rabbit complement (Low-tox, Cedarlane, Ontario, Canada) as reported (16). This cell fraction contained $<2 \%$ (range $0-2 \%$ ) residual mature $\mathrm{CD}^{+}, \mathrm{CD}^{+}$cells as assessed by immunofluorescence and flow cytometry studies, and will be referred to as $\mathrm{CD}^{-}$and $\mathrm{CD} 2^{-} \mathrm{CD}^{-}$cell fractions, respectively. In some experiments $\mathrm{CD}^{-}$or $\mathrm{CD}^{-} \mathrm{CD}^{-}$cells were further depleted of adherent cells by incubation in plastic petri dishes for $1 \mathrm{~h}$ at $37^{\circ} \mathrm{C}$ in $5 \%$ $\mathrm{CO}_{2}$ in air. Plastic adherence was followed by a complement-mediated cytotoxicity with the OKM1 MAb (Coulter Electronics Inc.). Adherent cell-depleted bone marrow subpopulations contained $<2 \%$ monocytes/macrophages when analyzed by indirect immunofluorescence and flow cytometry using the OKM1 MAb. Moreover, these cell fractions contained $<2 \% \mathrm{CD4}^{+}$cells when tested by flow cytometry. These cell populations will be referred to as $\mathrm{CD}^{-} \mathrm{A}^{-}$or $\mathrm{CD}^{-} \mathrm{CD}^{-} \mathrm{A}^{-}$cell fractions, respectively.

Cell infection. The various bone marrow subpopulations were incubated with 50 tissue culture $\mathrm{ID}_{50}$ units of HIV-1/106 cells in RPMI 1640 medium containing $2 \mu \mathrm{g} / \mathrm{ml}$ Polybrene (Sigma Chemical Co., St. Louis, MO) and sheep anti-human $\alpha$-interferon serum ( $40 \mathrm{U} / 10^{6}$ cells) for $1 \mathrm{~h}$ at $37^{\circ} \mathrm{C}$ in $5 \% \mathrm{CO}_{2}$ in air. Inactivated virus preparation (heated for $1 \mathrm{~h}$ at $56^{\circ} \mathrm{C}$ ) was incubated with bone marrow cells as a control. Subsequently the cells were washed three times with complete culture medium and their viability was tested. They were then resuspended in fresh culture medium at $10^{6} \mathrm{cells} / \mathrm{ml}$ and cultured in the presence of PHA (1\% vol/vol; Difco Laboratories, Inc., Detroit, MI) and the equivalent of 40 Biological Response Modifiers Program units $/ \mathrm{ml}$ from semipurified IL-2 (Biotest, W. Germany). Every third day total cell number, cell viability, cell phenotype, and $\mathrm{T}$ cell colony growth capacity were studied, whereas the supernatant was tested for reverse transcriptase (RT) activity as reported (1). The remaining cells were recultured in fresh culture medium supplemented with IL-2. All cultures were performed at $37^{\circ} \mathrm{C}$ in $5 \% \mathrm{CO}_{2}$ in air.

Phenotypic studies and expression of viral proteins. Cell phenotype was determined by indirect immunofluorescence using a panel of MAbs against the CD1(OKT6), CD3(OKT3), CD4(OKT4), CD8(OKT8; Ortho Pharmaceutical), and CD2 (T11; Coulter Electronics Inc.) molecules. Moreover, the expression of HIV proteins such as the gp120 and p24 was studied using the correspondent MAbs provided by Dupont de Nemours, Wilmington, DE. FITC-coupled goat anti-mouse Ig (Nordic Immunology, Tilburg, The Netherlands) was used as a second reagent. The cells were examined using an epifluorescence microscope (E. Leitz, Inc., Rockleigh, NJ).

In some experiments two-color immunofluorescence studies were performed as reported $(30,31)$ using MAbs coupled to phycoerythrin, fluorescein, or rhodamine. The samples were evaluated in the same fluorescence microscope equipped with a combination of blue (450-490 $\mathrm{nm}$ for FITC and phycoerythrin) and green (530-560 $\mathrm{nm}$ for rhodamine) excitation filters with stop filters at 515 and $580 \mathrm{~nm}$, respectively.

$T$ cell colony growth. $5 \times 10^{5}$ cells $/ \mathrm{ml}$ were seeded in $0.8 \%(\mathrm{vol} / \mathrm{vol})$ methylcellulose (Fluka AG, Buchs, Switzerland) in $\alpha$-MEM (Gibco Laboratories) supplemented with $15 \%$ (vol/vol) FCS and $2 \mathrm{mmol} \mathrm{L}-$ glutamine in the presence of PHA $(1 \% \mathrm{vol} / \mathrm{vol})$ and 40 Biological Response Modifiers Program units/ml rIL-2 (Biogen, Geneva, Switzerland) as reported $(26,27) .0 .1 \mathrm{ml}$ of the methylcellulose cell-containing preparation was seeded per well in 96-well, flat bottomed microtest plates and incubated at $37^{\circ} \mathrm{C}$ in $5 \% \mathrm{CO}_{2}$ in air for $5-7 \mathrm{~d}$. Aggregates containing $>50$ cells were counted under an inverted microscope as colonies.

Colonies of the same morphology and size were picked up individually and pooled. The cells were dissociated, and after washing were phenotyped as described above. In some experiments pooled colony cells were cocultured with 3-d PHA-stimulated normal PBL in RPMI 1640 supplemented with semipurified IL-2, $2 \mu \mathrm{g} / \mathrm{ml}$ Polybrene, and 40 $\mathrm{U} / 10^{6}$ cells sheep anti-human $\alpha$-interferon serum. Every third day the culture supernatant was tested for RT activity.

\section{Results}

Infection of T-depleted BMMC by HIV-1. It has been previously demonstrated that unfractionated BMMC can be infected and replicate HIV-1 (17). Since bone marrow aspirates frequently contain a variable degree of peripheral blood contamination $\left(8-25 \% \mathrm{CD}^{+}\right.$and $\mathrm{CD}^{+}$cells), we investigated whether $\mathrm{T}$ cell-depleted BMMC could be infected by HIV-1. As shown in Fig. $1, \mathrm{CD}^{-}$as well as $\mathrm{CD}^{-} \mathrm{CD}^{-}$BMMC were capable of replicating the virus. Indeed, virus production was detected at days 9-12 and peaked at day 15 , with very small variations in 10 different experiments. This pattern of virus replication was, in general, independent of the MAb used for the depletion of BMMC (Fig. 1). Conversely, no virus replication could be obtained from cultures incubated with heated virus preparations.

To more precisely define the target of HIV-1, $\mathrm{CD}^{-} \mathrm{CD}^{-} \mathrm{A}^{-} \mathrm{BMMC}$ were infected with HIV-1. As shown in Fig. 2, adherent cell depletion, either before or after cell infection, did not prevent virus replication. Since $\mathrm{CD} 2^{-} \mathrm{CD} 3^{-} \mathrm{A}^{-}$ bone marrow cells contained $<2 \% \mathrm{OKM1}^{+}$and $\mathrm{CD}^{+}$cells, this observation strongly suggests that HIV can directly infect some bone marrow cells distinct from mature $T$ and adherent cells. Immunofluorescence studies with FITC-coupled HIV demonstrated that $10 \%$ of the cells could bind the virus, as previously shown (17).

In vitro differentiation of HIV-1-infected, T-depleted $B M M C$. We have previously shown that HIV-1-infected subjects display significant abnormalities of the in vitro differentiation capacity of peripheral blood and bone marrow T-CFC $(26,27)$. Therefore, the effect of HIV-1 infection on the differentiation of immature bone marrow $T$ cells was studied. Fig. 3 $A$ indicates that noninfected T-depleted BMMC could differentiate progressively into $\mathrm{CD}^{+}(72 \%$ at day 12$), \mathrm{CD}^{+}(47 \%$ at day 16$)$, and $\mathrm{CD}^{+}(32 \%$ at day 12$)$ cells. $\mathrm{CD}^{+}$cells were always $<2 \%$ throughout the culture period (Fig. $3 \mathrm{~A}$ ). Conversely, in HIV-1-infected cultures of $\mathrm{CD}_{2} \mathrm{CD}^{-}$cells we observed an initial rise followed by a dramatic decrease in $\mathrm{CD}^{+}$ cells until day 16 , which corresponds to the peak of RT activity

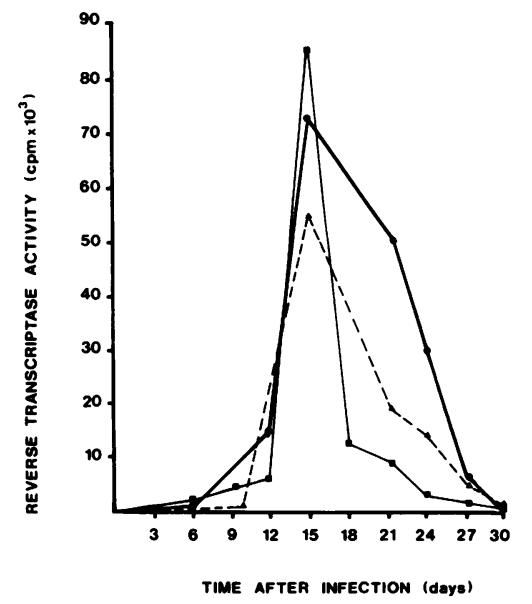

Figure 1. Replication of HIV-1 in different subpopulations of human BMMC. BMMC were depleted of mature T cells by complement mediated cytotoxicity using anti-CD2 and anti-CD3 MAbs. Unfractionated BMMC ( $\square)$, CD3-depleted (๑), and CD2,CD3-depleted (४) were infected with an HIV-1-containing supernatant and cells were cultured as described in Methods. Virus replication was evaluated by assaying the reverse transcriptase activity in the culture supernatant at different times of the culture. 


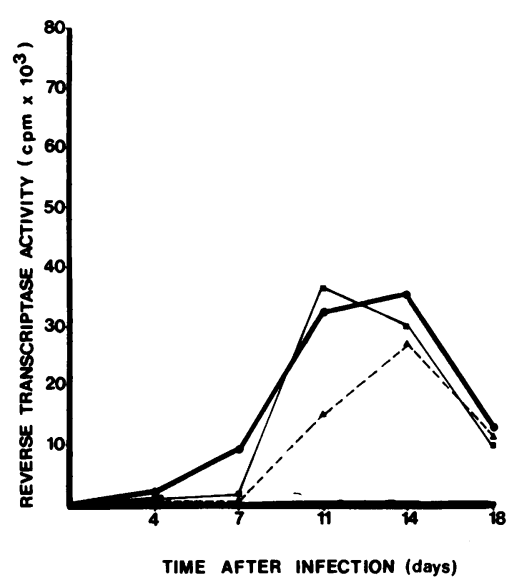

Figure 2. Replication of HIV-1 in adherent celldepleted $\mathrm{CD}^{-}{ }^{-} \mathrm{CD}^{-}$ BMMC: $\mathrm{CD}^{-} \mathrm{CD}^{-}$ BMMC were depleted of adherent cells by plastic adherence either before ( $\mathbf{\Delta})$ or after $(\boldsymbol{\square})$ HIV infection as described in Methods. Nondepleted $\mathrm{CD} 2^{-} \mathrm{CD}^{-}$cells $(\bullet)$ were used as controls. Results are expressed as the reverse transcriptase activity of the culture supernatant.

(Fig. $3 \mathrm{~B}$ ). In addition, these cultures contained a higher proportion of $\mathrm{CD}^{+}(52 \%$ at day 12$)$ and $\mathrm{CD}^{+}(24 \%$ at day 16$)$ cells (Fig. $3 \mathrm{~B}$ ). Similar findings were observed in infected cultures of $\mathrm{CD}^{-}$and $\mathrm{CD}^{-}$bone marrow (not shown).

Expression of $H I V-1$ proteins on infected $T$-depleted $B M M C$. Since the above findings strongly suggest that HIV-1 can induce significant abnormalities of $\mathrm{T}$ cell differentiation in vitro, it was interesting to determine whether $T$ cells are infected.

Immunofluorescence studies using a MAb against the HIV-1 envelope glycoprotein gp 120 revealed that 9 and $14 \%$ of the cells were positive at days 9 and 12 of the culture, respectively. No gp $120^{+}$cells could be revealed in control noninfected cultures. Moreover, double staining with anti-CD4 and anti-gp1 20 MAbs showed that 19 and $72 \%$ of the $\mathrm{CD}^{+}$cells expressed gp120 at days 9 and 12 of the culture, respectively. At day 15 the number of $\mathrm{CD}^{+}$was too low to evaluate accurately the presence of $\mathrm{gp} 120^{+}$cells. Similar experiments were also performed using a MAb against the $\mathrm{p} 24$ product of the gag gene. p24 was detected on $10 \%$ of the total cell population of the infected cultures at day 10 as well as on $83 \%$ of the $C D 4^{+}$ cells. No p $24^{+}$cells were observed in noninfected cells.

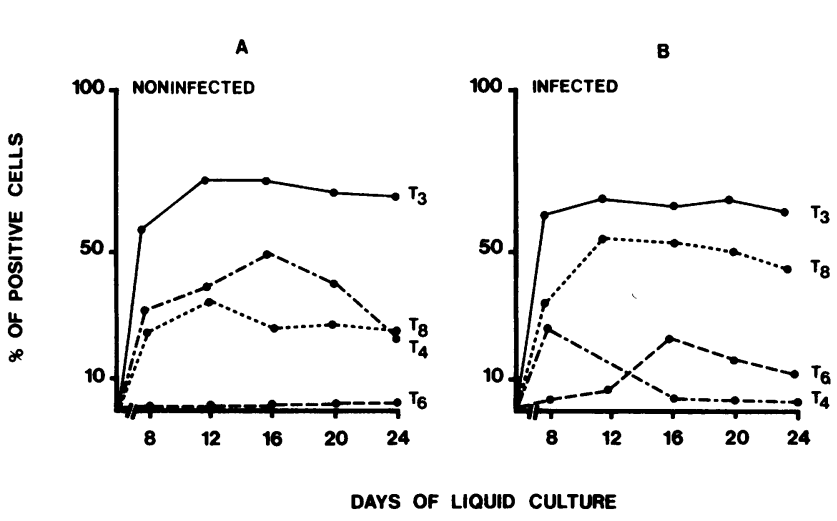

Figure 3. In vitro differentiation of $\mathrm{CD}^{-} \mathrm{CD}^{-}$BMMC after HIV-1 infection. Both noninfected $(A)$ and infected $(B)$ cells were phenotyped by indirect immunofluorescence throughout the culture period using various MAbs as described in Methods.

Thus, during the first $15 \mathrm{~d}$ of the culture the three following observations were made: $(a)$ increasing RT activity, $(b)$ expression of viral proteins on $\mathrm{CD} 4^{+}$cells, and $(c)$ disappearance of the $\mathrm{CD}^{+}$population. Taken together they strongly suggest that the virus replication, after infection of T-depleted BMMC, occurs in $\mathrm{CD}^{+}$cells that have differentiated in vitro during the culture period. To more precisely elucidate this point, HIV-1-infected T cell-depleted BMMC were depleted of $\mathrm{CD}^{+}, \mathrm{CD}^{+}$cells by complement-mediated cytotoxicity using the corresponding MAbs at day 9 , before the massive viral replication. $<2,000 \mathrm{cpm} / \mathrm{ml}$ of $\mathrm{RT}$ activity could be detected in these CD3- and CD4-depleted cultures during the subsequent $15 \mathrm{~d}$ of culture, whereas a significant virus replication $\left(\sim 30-40 \times 10^{3} \mathrm{cpm} / \mathrm{ml}\right.$ of RT activity) was observed in control cultures.

Effect of HIV-1 on the proliferation and differentiation of $T$-CFC. As shown in Fig. 4 the cloning capacity of T-CFC from the infected cultures of unfractionated BMMC (Fig. $4 \mathrm{~A}$ ), $\mathrm{CD}^{-}$(Fig. $4 \mathrm{~B}$ ), and $\mathrm{CD}^{-} \mathrm{CD}^{-}$(Fig. $4 \mathrm{C}$ ) cells was significantly decreased in comparison with the noninfected cultures. However, it is noteworthy that even the initial $1-\mathrm{h}$ incubation of the cells with the virus preparation resulted in a decrease of the plating efficiency (day 0; Fig. 4). The decrease of T-CFC colony growth was time dependent, reaching its maximum after the peak of RT activity.

The phenotypic study of pooled colony cells at day 15 revealed that colonies derived from noninfected $\mathrm{CD} 2^{-} \mathrm{CD} 3^{-}$ bone marrow cells were composed of $\mathrm{CD}^{+}(55-60 \%), \mathrm{CD}^{+}$ (42-38\%), and $\mathrm{CD}^{+}(25-30 \%)$ cells, whereas $\mathrm{CD1}^{+}$cells were always $<10 \%$ (Fig. $5 \mathrm{C}$ ). Conversely, colonies derived from infected $\mathrm{CD}^{-} \mathrm{CD}^{-}$bone marrow cells were composed of $50-55 \% \mathrm{CD}^{+}, 30-50 \% \mathrm{CD}^{+}, 22-32 \% \mathrm{CD}^{+}$, and $20-25 \%$ $\mathrm{CD}^{+}$cells (Fig. $5 \mathrm{C}$ ). A similar phenotype of colony cells was obtained when unfractionated BMMC (Fig. $5 A$ ) or CD3-depleted BMMC (Fig. $5 B$ ) were infected with HIV-1. In addition, double staining studies revealed that $18 \%$ of the $\mathrm{CD}^{+}$ colony cells also expressed the CD1 molecule, indicating the immature phenotype of some of the colony cells.

Infection of $T$ colony cells by HIV. Since $\mathrm{T}$ cell colonies derived from $\mathrm{HIV}$-infected $\mathrm{CD} 2^{-} \mathrm{CD}^{-}$normal BMMC display similar proliferation and differentiation abnormalities as the colonies observed in patients with LAS and AIDS, it was

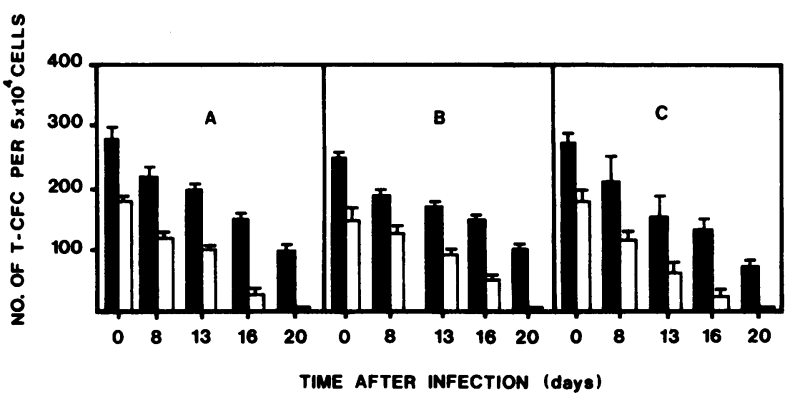

Figure 4. Study of $\mathrm{T}$ cell colony growth at various times after infection of BMMC by HIV-1. Unfractionated $(A), \mathrm{CD}^{-}(B)$, and $\mathrm{CD}^{-} \mathrm{CD}^{-}(C)$ BMMC were infected with HIV-1 as described. At different time periods a cell aliquot $\left(5 \times 10^{5}\right.$ cells $\left./ \mathrm{ml}\right)$ from both noninfected (solid bars) and infected (open bars) cultures was seeded in methylcellulose in the presence of PHA and rIL-2 as described in Methods. The results represent the mean number of colonies $\pm \mathrm{SD} / 5$ $\times 10^{4}$ cells from three replicate experiments. 


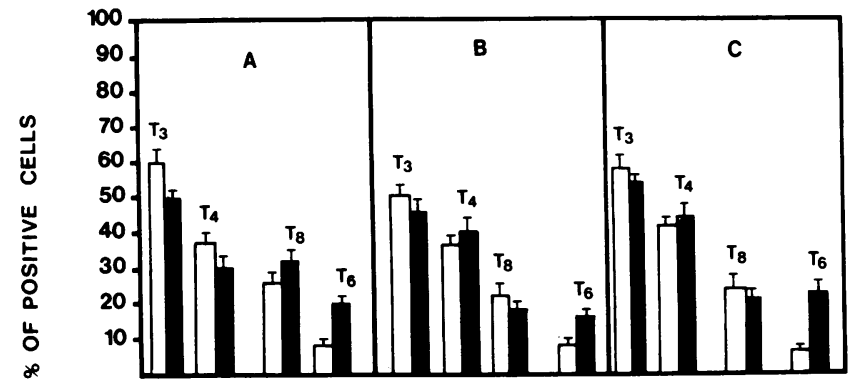

15 DAYS AFTER INFECTION

Figure 5. Phenotypic characterization of BMMC-derived colonies. Unfractionated $(A), \mathrm{CD}^{-}(B)$, and $\mathrm{CD}^{-} \mathrm{CD}^{-}(C) \mathrm{BMMC}$ were infected with HIV-1 as described. A cell aliquot was taken at day 15 of the culture and seeded in methylcellulose at $5 \times 10^{5}$ cells $/ \mathrm{ml}$ for $\mathrm{T}$ cell colony growth. Individual colonies from both noninfected (open bars) and infected (solid bars) cultures were picked up, pooled, and dissociated, and colony cells were phenotyped by indirect immunofluorescence as described in Methods. Results represent the mean value $\pm \mathrm{SD}$ of three replicate experiments.

interesting to study whether colony cells are infected by HIV-1. Indeed, $12-22 \%$ and $18-28 \%$ of the colony cells were expressing viral p24 at days 9 and 15, respectively. In addition, 5 and $9 \%$ of the p $24^{+}$colony cells at days 9 and 15 , respectively, also expressed the CD4 molecule. In parallel studies $24 \%$ of the colony cells expressed the gp 120 protein at day 10 . Finally, 8 and $13 \%$ of the gp $120^{+}$cells also displayed the CD1 and CD4 molecules, respectively, suggesting that a proportion of relatively immature $T$ cells were infected.

Expression of both gp 120 and p24 on colony cells indicates that at least a fraction of them are infected by HIV-1. To further prove this hypothesis, pooled colony cells were cocultured with normal PHA-activated PBL and culture supernatants were tested for RT activity. As shown in Fig. 6, pooled colonies obtained either at day 6 or 9 postinfection could infect normal activated lymphocytes. It is noteworthy that RT activity was detected earlier and was significantly higher in cocultures with day 9 than day 6 colony cells (Fig. 6).

\section{Discussion}

The results presented in this study clearly indicate that bone marrow cells depleted of mature $T$ cells could be infected and replicate HIV-1. Cell infection was independent of the MAb used for cell depletion since MAbs against both the CD3 and/ or CD2 molecules could not significantly modify the kinetics of virus replication (Fig. 1).

T-depleted BMMC is a heterogenous cell population including both relatively mature and immature cells of the granulopoietic, erythroid, B lymphoid, macrophage/monocyte lineages, as well as pluripotent and committed precursors of the various lineages. It has already been reported that monocytes and macrophages could present a latent HIV-1 infection (7). This cell population has been proposed to be an "in vivo reservoir" of the virus $(7,8)$. Our findings on HIV-1 infection of adherent cell-depleted BMMC indicate that adherent cells are not the limiting factor for cell infection, at least under our experimental conditions, and suggest that the virus can directly infect a nonadherent cell subpopulation of BMMC. The

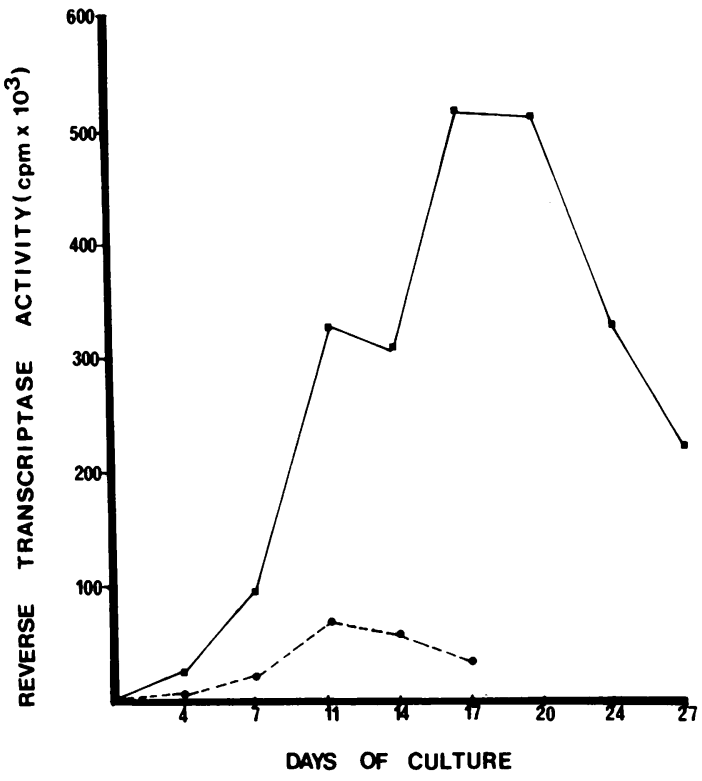

Figure 6. Infection of normal mitogen-activated lymphocytes by coculture with colony cells derived from infected $\mathrm{CD} 2^{-} \mathrm{CD} 3^{-}$BMMC. Pooled colony cells from $\mathrm{CD}^{-} \mathrm{CD}^{-}{ }^{-} \mathrm{BMMC}$ infected for $6(\bullet)$ and 9 (a) d were cocultured with normal activated lymphocytes as described in Methods. Virus replication was monitored by measuring the reverse transcriptase activity of the culture supernatant throughout the culture period.

slight delay in virus replication observed in BMMC that were depleted of adherent cells before infection seems to indicate that the presence of adherent cells facilitates cell infection and is in agreement with the hypothesis of the "in vivo reservoir" of adherent cells $(7,8)$. However, since no $\mathrm{CD}^{+}$cells could be detected in $\mathrm{CD}^{-} \mathrm{CD}^{-} \mathrm{A}^{-} \mathrm{BMMC}$ by flow cytometry studies, it is reasonable to hypothesize that molecules other than the CD4 may be used as the HIV-1 receptor on immature bone marrow cells as previously suggested (17).

The cell origin of the infected bone marrow cells seems to be immature $T$ cells. Indeed, two-color fluorescence staining could not reveal the expression of viral proteins (p24 or gp 120) on My9 or My7 cells throughout the culture period (not shown). It has recently been shown that in some patients' HIV isolation and propagation could be obtained when monocytes were treated with recombinant colony-stimulating factor 1 (32). Since the culture conditions used in the present study favor the proliferation of $T$ but not of myeloid cells, we cannot exclude a nonproductive viral infection of myeloid/monocytic cells. On the other hand, $T$ cells differentiating during the culture period were shown to be infected by HIV-1, since 19 and $72 \%$ of the $\mathrm{CD}^{+}$cells expressed the gp 120 at days 9 and 12 , respectively. This gp120 expression was not due to the binding of viral particles, since $83 \%$ of them also expressed the p24 core protein. This hypothesis is further supported by the kinetic data which clearly indicate that virus replication is followed by a dramatic decrease of the $\mathrm{CD} 4^{+}$cells; moreover, $\mathrm{CD}^{+}$cell depletion of cultured cells allowed a dramatic arrest of viral replication (Fig. 4). These observations suggest that T-depleted BMMC can be infected by the virus, but massive viral replication occurs only when immature $T$ cells are beginning to differentiate. 
The hypothesis of HIV infection of the immature T cells is strongly supported by the study of colony cells obtained after HIV-1 infection. $20-25 \%$ of the colony cells were $\mathrm{CD}^{+}$and double staining revealed cells that displayed both the CDI and CD4 molecules, indicating their immature cell phenotype (33) and, thus, an abnormal differentiation capacity of T-CFC. In addition, the expression of gp120 on $8 \%$ of $\mathrm{CDI}^{+}$cells clearly indicates the presence of HIV-1 in immature T cells. Furthermore, $12-22$ and $24 \%$ of the colony cells expressed p24 and gp120, respectively. However, direct evidence of the infection of colony cells with the virus was given by the capacity of pooled colonies to infect normal mitogen-activated lymphocytes. Since pooled colonies were used for coculture experiments we cannot exclude the possibility that only a proportion of these colonies are infected. Taken together the above observations demonstrate that HIV- 1 can infect $\mathrm{T}$ cell progenitors and be transmitted to their progeny, affecting the differentiation capacity of immature $\mathrm{T}$ cells.

HIV-1 infection of BMMC allowed an impaired proliferation of T-CFC. However, it is of note that even the initial $1-h$ incubation of the cells with the virus preparation resulted in a decrease of the plating efficiency (day 0; Fig. 4). Although HIV-1 infection of some immature $T$ cell precursors seems very likely, as reported above, this early effect of HIV on T-CFC proliferation is difficult to explain. Indeed, we cannot exclude the possibility that cell contact with HIV-1 triggers some inhibitory mechanisms that affect important molecular systems necessary for in vitro proliferation of T-CFC. We have reported that media conditioned by AIDS patients' adherent cells spontaneously produce an activity inhibiting the proliferation of normal T-CFC through decreased expression of the Tac chain of the IL-2-R and production of IL-2 (25). Moreover, Pahwa et al. (24) have shown that disrupted viral preparations are also capable of inhibiting the expression of IL-2-R, whereas Mann et al. (23) have reported that immunopurified gp120 from HIV could inhibit the mitogenic stimulation of lymphocytes. The inhibitory effect of viral proteins is still controversial since other studies have shown that both p24 and gp 120 could induce in vitro specific T cell responses in HIVinfected subjects (34) as well as in immunized animals (35). However, it seems unlikely that inhibitory activities produced by infected cells or by gp120 could be expressed as soon as $1 \mathrm{~h}$ after HIV-1 infection. Therefore, other mechanisms such as membrane modifications due to virus cell binding and penetration might be involved in this immediate inhibition of T-CFC proliferation.

The impaired proliferation and abnormal differentiation capacity of T-CFC observed in cultures infected in vitro are very similar to those observed in vivo in HIV-1-infected subjects (26-29). Indeed, we and others have previously demonstrated that T-CFC from patients with HIV-1 infection (asymptomatic seropositive subjects, AIDS and LAS patients) display significant abnormalities of their in vitro proliferation capacity (26-29). Moreover, patients' T-CFC display an abnormal in vitro differentiation capacity since colony cells expressed, in a high proportion, the CD1 molecule (26-28) that characterizes immature $T$ cells (33). Therefore, our findings support a pathophysiological scheme of immature $\mathrm{T}$ cell progenitor infection: HIV-1 can infect, either directly or indirectly (i.e. through a nonadherent bone marrow cell), immature $\mathrm{T}$ cells which do not seem capable of massively replicating the virus. However, HIV-1 is transmitted to the progeny and is replicated when the cells differentiate into common and/or late thymocytes expressing the CD4 molecule. In this case, we hypothesize that immature or poorly differentiated $\mathrm{T}$ cells could possess some regulatory mechanisms that do not favor virus replication. The elucidation of these mechanisms is very important for the understanding of the latent or productive HIV-1 infection. In addition, in vitro bone marrow cell infection with HIV-1 could provide a useful model to evaluate the effect of various agents, potentially active, in the treatment of AIDS patients.

\section{Acknowledgments}

We are grateful to Mrs. Nadiège Balliet for secretarial help with the manuscript, to Dr. M. Allouche for her helpful suggestions, and to Drs. C. Boucheix, G. Andreu (Hôpital Hôtel Dieu), F. Beaujean (Hôpital Henri Mondor), and E. Lopez (Hôpital Saint Antoine) for providing us with normal bone marrow cells.

This work was supported by grants from the Association de la Recherche contre le Cancer, the Ligue Nationale contre le Cancer, and the Foundation de la Recherche Médicale. Yanto Lunardi-Iskandar is the recipient of a fellowship from the Fondation de la Recherche Médicale.

\section{References}

1. Barré-Sinoussi, F., J. C. Chermann, F. Rey, M. T. Nugeyre, S. Chamaret, J. Gruest, C. Dauget, C. Axler-Blin, F. Vesinet-Brun, C. Rouzioux, W. Rozenbaum, and L. Montagnier. 1983. Isolation of a T-lymphotropic retrovirus from a patient at risk for AIDS. Science (Wash. DC). 204:868-871.

2. Popovic, M., M. G. Sarngadharan, E. Read, and R. C. Gallo. 1984. Frequent detection and isolation of cytopathic retrovirus (HTLV-III) from patients with AIDS and at risk for AIDS. Science (Wash. DC). 224:497-500.

3. Klatzmann, D., E. Champagne, S. Chamaret, J. Gruest, D. Guetard, T. Hercend, J. C. Gluckman, and L. Montagnier. 1984. Tlymphocyte $\mathrm{T} 4$ molecule behaves as the receptor for human retrovirus LAV. Nature (Lond.). 312:767-768.

4. Dalgleish, A. G., P. C. L. Beverley, P. R. Clapham, D. H. Crawford, M. F. Greaves, and R. A. Weiss. 1984. The CD4 (T4) antigen is an essential component of the receptor for AIDS retrovirus. Nature (Lond.). 312:763-767.

5. Yarchoan, R., R. R. Redfield, and S. Broder. 1986. Mechanisms of $B$ cell activation in patients with acquired immunodeficiency syndrome and related disorders. Contribution of antibody-producing $B$ cells, of Epstein-Barr virus-infected B cells, and of immunoglobulin production induced by human T cells lymphotropic virus, type III/ lymphadenopathy-associated virus. J. Clin. Invest. 78:439-447.

6. Montagnier, L., J. Guest, and S. Chamaret. 1984. Adaptation of lymphadenopathy associated retrovirus (LAV) to replication in EBVtransformed B lymphoblastoid cell lines. Science (Wash. DC). 25:6366.

7. Salahuddin, S. Z., R. M. Rose, J. E. Groopman, P. D. Markham, and R. C. Gallo. 1986. Human T lymphotropic virus type III infection of human alveolar macrophages. Blood. 68:281-284.

8. Gartner, S., P. Markovits, D. M. Markovits, M. H. Kaplan, R. C. Gallo, and M. Popovic. 1986. The role of mononuclear phagocytes in HTLV III/LAV infection. Science (Wash. DC). 233:215-219.

9. Wiley, C. A., R. D. Schrier, J. A. Nelson, P. W. Lampert, and M. B. Oldstone. 1986. Cellular localization of human immunodeficiency virus infection within the brains of acquired immune deficiency syndrome patients. Proc. Natl. Acad. Sci. USA. 83:7089-7094.

10. Gyorkey, F., J. L. Melnick, and P. Gyorkey. 1987. Human immunodeficiency virus in brain biopsies of patients with AIDS and progressive encephalopathy. J. Infect. Dis. 155:870-876. 
11. Petito, C. K., E. S. Cho, W. Lemann, B. A. Navia, and R. W. Price. 1986. Neuropathology of acquired immunodeficiency syndrome (AIDS): an autopsy review. J. Neuropathol. \& Exp. Neurol. 45:635-646.

12. Gartner, S., P. Markovits, D. M. Markovits, R. F. Betts, and M. Popovic. 1986. Virus isolation from and identification of HTLV III/ LAV-producing cells in brain tissue from a patient with AIDS. JAMA (J. Am. Med. Assoc.). 256:2365-2371.

13. Dalgleish, A. G., P. C. L. Beverly, P. R. Clapham, P. H. Crawford, M. F. Greaves, and R. A. Weiss. 1985. The CD4 (T4) antigen is an essential component of the receptor for the AIDS retrovirus. Nature (Lond.). 312:763-767.

14. Klatzmann, D. E., E. Champagne, S. Chamaret, J. Gruest, D. Guetard, T. Hercend, J. C. Gluckman, and L. Montagnier. 1984. T lymphocyte $\mathrm{T} 4$ molecule behaves as the receptor for human retrovirus LAV. Nature (Lond.). 312:763-767.

15. Mc Dougal, J. S., M. S. Kennedy, J. M. Sligh, S. P. Cort, A. Mawle, and J. K. A. Nicholson. 1986. Binding of HTLV-III/LAV to $\mathrm{T4}^{+} \mathrm{T}$ cells by a complex of the $110 \mathrm{k}$ viral protein and the $\mathrm{T} 4$ molecule. Science (Wash. DC). 231:382-385.

16. Mc Dougal, J. S., J. K. A. Nicholson, J. D. Cross, S. P. Cort, M. S. Kennedy, and A. C. Mawle. 1986. Binding of the human retrovirus HTLV-III/LAV/ARV/HIV to the CD4 (T4) molecule: conformation dependence, epitope mapping, antibody inhibition, and potential for idiotypic mimicry. J. Immunol. 137:2937-2944.

17. Achour, A., U. Hazan, M. T. Nugeyre, F. Barré-Sinoussi, P. Metegran, H. Gachelin, F. Chapuis, D. Klatzmann, and J. C. Gluckmann. 1988. A binding assay to identify HIV (LAV) target cells. Ann. Inst. Pasteur (Paris). 137:291-302.

18. Fauci, A. S. 1988. The human immunodeficiency virus: infectivity and mechanisms of pathogenesis. Science (Wash. DC). 239:617-622.

19. Harper, E. M., L. M. Marselle, R. C. Galo, and F. Wong-Staal. 1986. Detection of lymphocytes expressing human T-lymphotropic virus type III in lymph nodes and peripheral blood from infected individuals by in situ hybridization. Proc. Natl. Acad. Sci. USA. 83:772-776.

20. Claesson, M. H., M. B. Rodger, G. R. Johnson, S. Wittingham, and D. Metcalf. 1977. Colony formation by human lymphocytes in agar medium. Clin. Exp. Immunol. 28:526-532.

21. Rozenszajn, L. A., D. Shohaw, and I. Kalecheman. 1975. Clonal proliferation of PHA stimulated human lymphocytes in soft agar culture. Immunology. 29:1044-1052.

22. Georgoulias, V., S. Marion, R. Consolini, and C. Jasmin. 1985. Characterization of normal peripheral blood T and B-cell colony forming cells: growth factor(s) and accessory cells requirements for their in vitro proliferation. Cell. Immunol. 90:1-13.

23. Mann, L. D., F. Lasane, M. Popovic, L. O. Arthur, W. G. Robbey, W. A. Blattner, and M. J. Newman. 1987. HTLV-III large envelope protein ( $\mathrm{gp} 120$ ) suppresses PHA-induced lymphocyte blastogenesis. J. Immunol. 138:2640-2644.

24. Pahwa, S., R. Pahwa, C. Saxinger, R. C. Gallo, and R. A. Good. 1985. Influence of the human $T$ lymphotropic virus/lymphadenopathy associated virus on functions of human lymphocytes: evidence for immunosuppressive effects and polyclonal B cell activation by banded viral preparation. Proc. Natl. Acad. Sci. USA. 82:8198-8202.

25. Lunardi-Iskandar, Y., V. Georgoulias, D. Vittecoq, M. T. Nugeyre, A. Ammar, C. Clemenceau, F. Barré-Sinoussi, J. C. Chermann, L. Schwartzenberg, and C. Jasmin. 1987. Peripheral blood adherent cells from AIDS patients inhibit normal T-colony growth through decreased expression of interleukin 2-receptors and production of interleukin 2. Leuk. Res. 11:753-760.

26. Lunardi-Iskandar, Y., V. Georgoulias, M. Allouche, W. Rozenbaum, D. Klatzmann, M. Cavaille-Colle, P. Meyer, D. Gluckmann, M. Gentilini, and C. Jasmin. 1985. Abnormal in vitro proliferation and differentiation of T-colony forming cells in AIDS patients and clinically normal male homosexuals. Clin. Exp. Immunol. 60:285293.

27. Lunardi-Iskandar, Y., V. Georgoulias, W. Rozenbaum, D. Klatzmann, M. Cavaille-Coll, P. Meyer, M. Gentilini, J. C. Gluckmann, and C. Jasmin. 1986. Abnormal in vitro proliferation and differentiation of T-colony forming cells in patients with lymphadenopathy syndrome (LAS). Blood. 67:1063-1089.

28. Lunardi-Iskandar, Y., V. Georgoulias, W. Rozenbaum, D. Vittecoq, P. Meyer, M. Gentilini, and C. Jasmin. 1986. AIDS and lymphadenopathy syndrome (LAS) patients display similar abnormal in vitro proliferation and differentiation of T-colony forming cells (T-CFC). Cancer Detect. Prev. 1:525-533.

29. Wilkenstein, A., R. S. Klein, T. L. Evans, B. N. Dixon, W. L. Holder, and L. D. Weaver. 1985. Defective in vitro T-cell colony formation in the acquired immunodeficiency syndrome. J. Immunol. 134:151-156.

30. Bentaboulet, M., M. Allouche, A. Tsapis, and V. Georgoulias. 1987. Characterization of IL2-receptors expressed on acute leukemic B-cells. Blood. 70:954-959.

31. Lanier, L. L., A. M. Le, A. H. Ding, and E. L. Evans. 1987. Analysis of the workshop T-cell monoclonal antibodies by "indirect two colour immunofluorescence" and multiparameter flow cytometry. In Leucocyte Typing III: White Cell Differentiation Antigens. A. J. Mc Michael, editor. 62-65.

32. Gendelman, H. E., J. M. Orenstein, M. A. Martin, C. Ferrua, R. Mitra, T. Phipps, L. A. Wahl, H. C. Lane, A. S. Fauci, D. S. Burke, D. Skillman, and M. S. Meltzer. 1988. Efficient isolation and propagation of human immunodeficiency virus on recombinant colony-stimulating factor-1-treated monocytes. J. Exp. Med. 167:1428-1441.

33. Reinherz, E. L., and S. F. Schlossman. 1980. The differentiation and function of human T cell lymphocytes. Cell. 19:821-829.

34. Wahren, B., L. Morfeldt-Minsson, G. Biberfeld, L. Moberg, A. Sönnenborg, P. Ljuigman, A. Werner, R. Kurth, R. Gallo, and D. Bolognes. 1987. Characteristics of the specific cell-mediated immune response in human immunodeficiency virus infection. J. Virol. 61:2017-2023.

35. Krohn, K., W. G. Robey, S. Putney, L. Arthur, P. Nara, P. Fischinger, R. C. Gallo, F. Wong-Staal, and A. Ranki. 1987. Specific cellular immune response and neutralizing antibodies in goats immunized with native or recombinant envelope protein derived from human T-lymphotropic virus type III $_{B}$ and in human immunodeficiency virus-infected men. Proc. Natl. Acad. Sci. USA. 84:4994-4998. 